\title{
Kinesin Superfamily-associated Protein 3 (KAP3) Mediates the Interaction between Kinesin-II Motor Subunits and HS-1-associated Protein X-1 (HAX-1) through Direct Binding
}

\author{
Won Hee Jang and Dae-Hyun Seog* \\ Departments of Biochemistry, College of Medicine and UHRC, Inje University, Busan 614-735, Korea
}

Received August 1, 2013 /Revised August 16, 2013 / Accepted August 16, 2013

\begin{abstract}
Kinesin-II, a molecular motor, consists of two different motor subunits, KIF3A and KIF3B, and one large kinesin superfamily-associated protein 3 (KAP3), forming a heterotrimeric complex. KAP3 is associated with the tail domains of motor subunits. However, its exact role remains unclear. Here, we demonstrated KAP3 binding to the carboxyl (C)-terminal tail region of HS-associated protein X-1 (HAX-1). HAX-1 bound to the C-terminal region of KAP3, but not to KIFs (KIF3A, KIF3B, and KIF5B) and the kinesin light chain (KLC) in the yeast two-hybrid assays. The interaction was further confirmed in the glutathione $S$-transferase (GST) pull-down assay and by co-immunoprecipitation. Anti- HAX-1 antibody as well as anti-KIF3A antibody co-immunoprecipitated KIF3B and KAP3 from mouse brain extracts. These results suggest that KAP3 could mediate the interaction between Kinesin-II and HAX-1.
\end{abstract}

Key words : Microtubule motors, kinesin-II, kinesin superfamily-associated protein 3 (KAP3), HS-associated protein $\mathrm{X}-1$ (HAX-1), adaptor proteins, protein-protein interaction

\section{Introduction}

Kinesins are motor proteins that utilize ATP hydrolysis to drive the transport of cargoes along microtubules [2]. Kinesin-II is the amino (N)-terminal motor domain member of Kinesin superfamily (KIF) [9]. It is a heterotrimeric complex of three dissimilar subunits, two motor subunits (KIF3A and KIF3B) and a larger non-motor protein (kinesin superfamily-associated protein 3, KAP3) [7]. KIF3A and KIF3B were shown to bind to each other through the coiled-coil stalk domains, while KAP3 was proposed to bind to the tail region of the motor subunits [8]. Kinesin-II is a versatile motor involved in multiple different transports involving a large variety of cargoes [7]. Kinesin-II is ubiquitously expressed, with abundant expression in nerve tissue [8]. Microinjection and immunoprecipitation by anti-KIF3B antibody revealed that Kinesin-II is thought to play a role in anterograde axonal transport in neuron [22].

In the nerve axons, the formation of cilia and flagella needs the transport of various proteins to the nerve terminal

\footnotetext{
*Corresponding author

Tel : +82-51-890-6974, Fax : +82-51-894-5801

E-mail : daehyun@inje.ac.kr

This is an Open-Access article distributed under the terms of the Creative Commons Attribution Non-Commercial License (http://creativecommons.org/licenses/by-nc/3.0) which permits unrestricted non-commercial use, distribution, and reproduction in any medium, provided the original work is properly cited
}

along microtubules. Chlamydomonas KIF3 homolog FLA10 was localized in flagella and highly concentrated around the flagellar basal bodies [15]. Caenorhabditis elegans KIF3 homo$\log$ Osm3 is essential for the assembly of the cilia of sensory neurons [16]. Kinesin-II in sea urchin has been localized in the connecting cilia. Kinesin-II was shown to be involved in ciliogenesis in the sea urchin embryo. Microinjection of anti-Kinesin-II antibody disrupted the formation of cilia [21]. Thus, Kinesin-II plays important roles in anterograde intraflagellar transport for the flagella and cilia formation in many species and cell types [8]. Interestingly, knockout mice for Kinesin-II genes showed the randomization of left-right asymmetry [8] which is implicated in certain chronic human disorders such as Bardet-Biedl syndrome [4] and polycystic kidney disease [13].

Previous genetic studies suggest that KAP3 plays an important role in Kinesin-II functions. Mutation in the FLA3, a Chlamydomonas $K A P 3$ homolog, was shown to cause loss of the anterograde intraflagellar transport [12, 15]. In Drosophila, mutation in the DmKAP3 eliminated the sensory cilia of neurons [18]. Similarly, mutation in the Caenorhabditis elegans $K A P 3$ was shown to affect the Kinesin-II mediated transport into the sensory cilia [16]. However, a study with recombinant KIF3A/KIF3B and KAP3 suggested that KAP3 has no effect on the motor activity of Kinesin-II [23]. Human KAP3 was shown to mediate the regulation of the interaction of small $G$ proteins implicated in vesicle transport with 
membranes [19]. Therefore, KAP3 may control the binding of Kinesin-II to vesicular cargoes through the interaction with small $\mathrm{G}$ proteins located at membranes. On the basis of these observations, it could be speculated that KAP3 may function as a cargo adapter for Kinesin-II.

Understanding how Kinesin-II binds to its specific cargo is an important question. In this study, we screened for proteins that bind to KAP3 and found an interaction with HS-1-associated protein X-1 (HAX-1). HAX-1 was originally identified as a $35 \mathrm{kDa}$ protein that interacts with HS-1, a Src kinase substrate [5]. The KAP3 and HAX-1 interaction suggests that Kinesin-II may transport HAX-1 containing cargo along microtubules in cells.

\section{Materials and Methods}

\section{Plasmid constructs}

Full-length mouse $H A X$-1 (accession NM_011826.3), and KAP3 (accession NM_010629.2) were amplified by polymerase chain reaction (PCR) from Marathon-Ready ${ }^{\mathrm{TM}}$ CDNA library (Clontech, Palo Alto, CA, USA) and cloned into pGEM T-easy vector (Promega Corp, Madison, WI, USA). The C-terminal region of KAP3 was utilized as a template to amplify the region coding for amino acids 320-772 using the specific primers [23]. The amplified fragment was cloned into $\mathrm{pGEM}$ T-easy vector (Promega). The resulting recombinant plasmid was then cut with EcoKI and $X$ hd and the insert was subcloned into pLexA (Clontech), pJG4-5 (Clontech), and pET41 (Novagen, San Diego, CA, USA).

\section{Screening of KAP3-binding proteins by yeast two- hybrid system}

The Matchmaker LexA two-hybrid system was used for screening according to the manufacturer's manual (Clontech). In brief, the yeast strain EGY48 carrying the p8op-lac $Z$ reporter plasmid was transformed with pLexA-KAP3. The yeast cells were subsequently transformed with the mouse brain cDNA library [22] and grown on synthetic dextrose (SD) plates supplemented with glucose but with no histidine, tryptophan, or uracil (SD/-His/-Trp/-Ura). The selection of positive clones was performed on an SD/-His/ -Trp/-Ura/-Leu plate containing galactose, raffinose, X-gal, and BU salts. Plasmids from positive clones were analyzed by digestion with EcolI and $X h d$. Unique inserts were sequenced and protein sequence analysis was performed with the BLAST algorithm at the National Center for Biotechnol- ogy Information (NCBI). Sequence-verified clones were tested again for interactions of with the bait in yeast by retransformation.

$\beta$-Galactosidase activity in liquid cultures of yeast

The $\beta$-galactosidase activity of yeast was assayed as described previously [11, 22]. Mid-log phase yeast cells were collected and permeabilized with $0.1 \%$ sodium dodecyl sulphate (SDS) and chloroform. An excess amount of o-nitrophenyl- $\beta$-D-galactoside (ONPG) was added to yeast lysate, and the mixture was incubated at $30^{\circ} \mathrm{C}$, and then the reaction was stopped by increasing $\mathrm{pH}$ to 11 by the addition of 1 $\mathrm{M} \mathrm{Na}_{2} \mathrm{CO}_{3}$. The formation of the reaction product, o-nitrophenol, was determined by measuring absorbance at $420 \mathrm{~nm}$ on a spectrophotometer and normalizing for the reaction time. The units of enzyme activity were calculated by the following equation: units $=1000 \times\left[\left(\mathrm{OD}_{420}-1.75 \times \mathrm{OD}_{550}\right)\right] /$ (reaction time $\times$ culture volume $\times \mathrm{OD}_{600}$ ). All experiments were independently performed at least four times [1].

\section{Co-immunoprecipitation and Immunoblot analysis}

Mouse brains were homogenized in ice-cold homogenization buffer (0.32 M sucrose, $4 \mathrm{mM}$ HEPES, pH 7.3) supplemented with protease inhibitor cocktail (Sigma-Aldrich, St. Louis, MO, USA). For immunoprecipitation, mouse brain lysate was diluted in the same volume of $2 \mathrm{X}$ binding buffer (50 mM HEPES, $200 \mathrm{mM} \mathrm{KCl}, 0.2 \%$ Triton X-100, pH 7.0) and incubated with anti-HAX-1 antibody (Santacruz Biotechnology, Santa Cruz, CA, USA), anti-KIF3A antibody [22], or control IgG overnight at $4^{\circ} \mathrm{C}$, followed by precipitation with protein-A Sepharose (Amersham Pharmacia, Piscataway, NJ, USA). The beads were collected by brief centrifugation and washed three times with TBS-T $(20 \mathrm{mM}$ Tris- $\mathrm{HCl}$, $\mathrm{pH} 7.5$, $0.2 \mathrm{M} \mathrm{NaCl}, 0.1 \%$ Tween 20). The washed beads were resuspended with Laemmlis loading buffer and the proteins were eluted and denatured by boiling for $2 \mathrm{~min}$ and then separated by SDS-PAGE. The proteins were transferred from the gel to a nitrocellulose membrane and incubated with anti-KAP3 [23], anti-KIF3B [23], and anti-HAX-1 antibodies.

Glutathione S-transferase (GST) pull-down assays cDNA encoding the C-terminal region of HAX-1 was cloned into pET41a. The recombinant GST-HAX-1 fusion protein was expressed in bacterial strain BL21 GOLD (Stratagene, La Jolla CA, USA) after induction with $0.5 \mathrm{mM}$ isopropyl thio- $\beta$-D-galactopyranoside (IPTG) for $3 \mathrm{hr}$. The 
fusion proteins were purified using glutathione-agarose beads (Sigma-Aldrich) according to the manufacturer's protocol. The mouse brain S2 fraction was incubated overnight at $4{ }^{\circ} \mathrm{C}$ with the GST fusion protein-coupled glutathione beads. The beads were pelleted by centrifugation, washed three times with the extraction buffer (1\% Triton X-100 in PBS containing $10 \mu \mathrm{g} / \mathrm{ml}$ each aprotinin, leupeptin, and pepstatin and $1 \mu \mathrm{M}$ phenylmethanesulfonyl fluoride), and once with PBS. The bound proteins were eluted from the glutathione beads with $100 \mu \mathrm{l}$ of Laemmli s loading buffer. The pulled-down proteins were analyzed by immunoblotting with anti-KIF3A, anti-KIF3B, anti-KIF5B, and anti-KAP3 antibodies $[10,23]$.

\section{Results}

\section{Identification of KAP3 interacting proteins by yeast two-hybrid system}

To identify KAP3 interacting proteins, we screened a mouse brain cDNA library by yeast two-hybrid system using the C-terminal region (aa 320-772) of KAP3 as bait. From $5 \times 10^{6}$ colonies screened, we obtained 4 positive clones. Two clones (clone 1 and 3 ) of the 4 clones were identical and possessed cDNA fragments corresponding to the C-terminal region of HAX-1 (Fig. 1A). HAX-1 was isolated as HS-1 interacting protein and suggested to be involved in $\mathrm{B}$ cell signal transduction [20]. HAX-1 contains several protein-protein interaction domains, the putative two $\mathrm{Bcl}-2$ homology $(\mathrm{BH})$ domains and one proline, glutamic acid, serine, threonine (PEST) domain. The C-terminus of HAX-1 has the putative transmembrane domain (TMD) [5]. To determine the minimal binding domain of HAX-1 that is required for the interaction with KAP3, we constructed several deletion mutants of HAX-1. Yeast two-hybrid assays showed that the minimal domain required for binding was located in the C-terminal region of HAX-1 (Fig. 1A). Unexpectedly, KAP3 did not interact with the putative protein-protein interaction domains within the N-terminal region of HAX-1. Next, we determined the minimal binding domain of KAP3. We constructed several deletion mutants of KAP3 and tested the interaction with HAX-1 by yeast two-hybrid assays. The interaction with HAX-1 was dependent on the C-terminal region of KAP3 (Fig. 1B). Together, these results show that the interaction between KAP3 and HAX-1 is mediated through their C-terminal regions.

Next we investigated whether HAX-1 interacts with

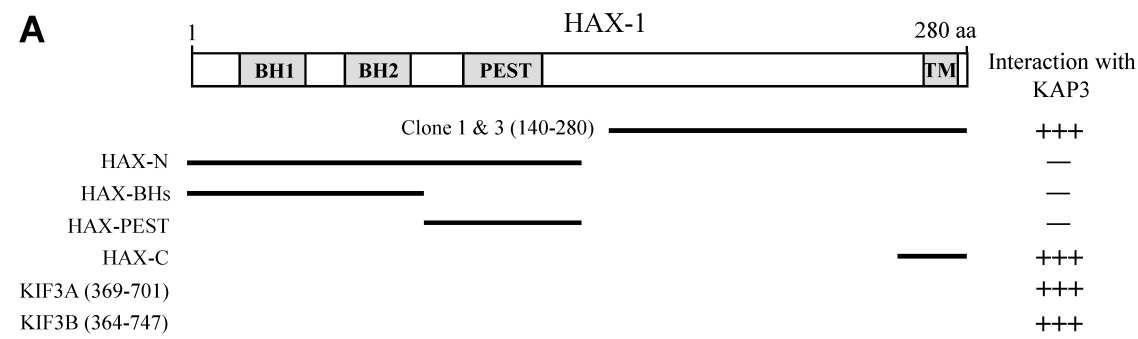

B

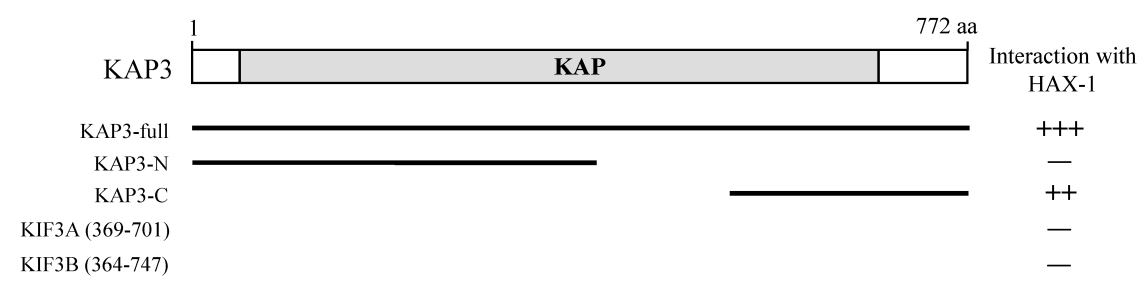

Fig. 1. Identification of the proteins interacting with KAP3 by yeast two-hybrid screening. (A) The domain structure of HAX-1 illustrating that clones 1 and 3 corresponds to the C-terminal fragment of HAX-1. The putative BH, PEST, and TM domains are indicated in gray. To determine minimal KAP3 binding region and binding specificity of HAX-1, several truncated forms of HAX-1, KIF3A, and KIF3B were constructed by PCR and tested in the yeast two-hybrid assay for interaction with KAP3. +++ , interaction with KAP3; -, no interaction with KAP3. aa, the amino acid residue number. (B) The C-terminal region of KAP3 mediates interaction with HAX-1. KAP3 has a KAP domain, depicted as the gray box. Several truncated forms of KAP3, KIF3A, and KIF3B were constructed by PCR and tested in the yeast two-hybrid assay for interaction with HAX-1. ++ or +++ , interaction with HAX-1; -, no interaction with HAX-1. aa, the amino acid residue number. 
A

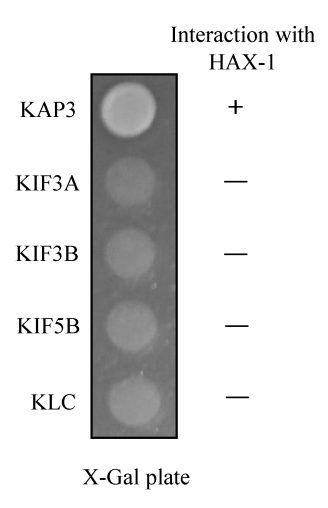

B

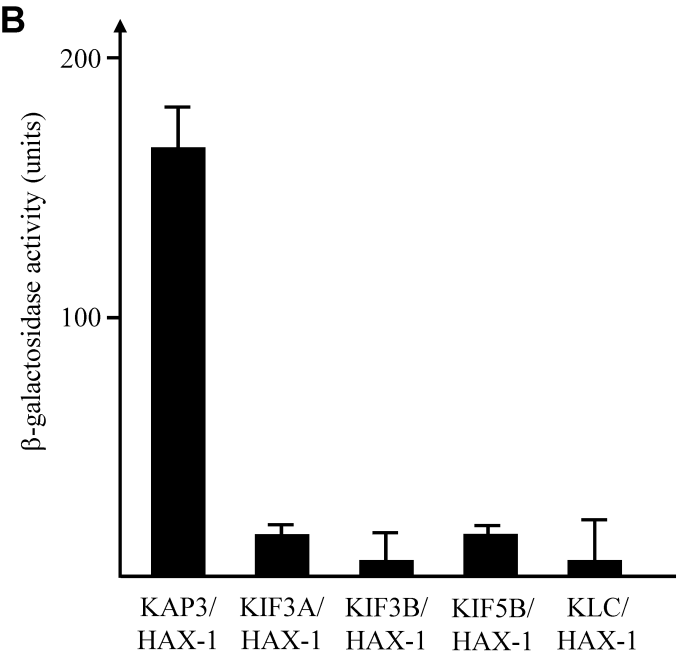

Fig. 2. Interaction between KAP3 and HAX-1. (A) The C-terminal regions of each KIF, KAP3, and KLC were fused to the pLexA DNA binding domain. HAX-1 specifically interacted with KAP3 but not with KIFs and KLC. +, interaction; -, no interaction. (B) The strength of interactions between KIFs, KAP3, or KLC and HAX-1 were examined quantitatively using $\beta$-galactosidase activity in yeast two-hybrid reporter assay.

KIF3A and KIF3B subunits of Kinesin-II and KIF5B and kinesin light chain 1 (KLC1) subunits of Kinesin-I. As shown in Fig. $1 B, 2 A$, and $2 B$, there was no detectable binding of HAX-1 with KIF3A, KIF3B, KIF5B, and KLC1. A quantitative $\beta$-galactosidase assay showed that HAX-1 directly bound to KAP3 but not to KIFs (Fig. 2B). These data indicate that the interaction of KAP3 with HAX-1 is specific.

\section{$\mathrm{HAX}-1$ is associated with Kinesin-II}

Kinesin-II is composed of a KIF3A/KIF3B heterodimer and KAP3, forming a heterotrimeric complex [23]. Therefore, we next determined whether HAX-1 interacts specifically with KAP3 and whether the interaction includes Kinesin-II at the protein level using GST pull-down experiments. Recombinant GST-HAX-1 fusion protein was expressed in E. coli. The purified GST fusion protein was allowed to interact with mouse brain lysates. Immunoblotting analyses revealed that KAP3 interacted with GST-HAX-1, but not with GST. In addition, KIF3A and KIF3B, which bind to the KAP3, were efficiently precipitated with GST-HAX-1 (Fig. 3A). This indicates that HAX-1 interacts with Kinesin-II.

To further confirm whether the binding of KAP3 to HAX-1 mediates the interaction between Kinesin-II and HAX-1, we performed co-immunoprecipitation analyses. Lysates from mouse brain were incubated with anti-HAX-1 antibody or anti-KIF3A antibody. Protein A-Separose beads precipitated the immuno-complexes, which were then subsequently separated by SDS-PAGE and immunoblotted with
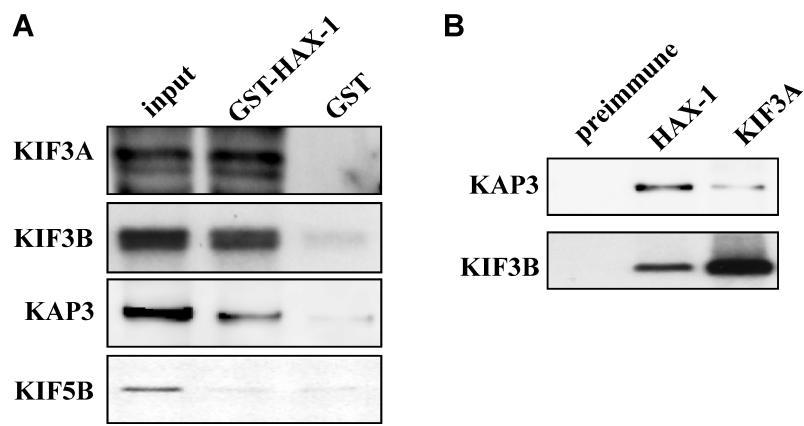

Fig. 3. Association of Kinesin-II with HAX-1 in the GST pulldown assay and co-immunoprecipitation. (A) Proteins in the mouse brain lysate were allowed to bind to GST alone or GST-HAX-1 fusion proteins. The elution fractions were resolved by SDS-PAGE and analyzed by immuoblotting using anti-KIF3A, KIF3B, KAP3, or KIF5B antibodies. (B) Mouse brain lysates were immunoprecipitated with anti-KIF3A, HAX-1 antibodies, or preimmune serum, and then the precipitates were immunoblotted with anti-KAP3, or KIF3B antibodies.

anti-KAP3 and anti-KIF3B antibodies. As shown in Fig. 3B, both anti-HAX-1 and anti-KIF3A antibodies efficiently precipitated the Kinesin-II complex, KIF3A/KIF3B heterodimer and KAP3. These results suggest that the interaction of HAX-1 with Kinesin-II is mediated by KAP3.

\section{Discussion}

In the search for proteins interacting with KAP3 we have shown that HAX-1, a multifunctional protein can associate 
with KAP3. Using the C-terminal region of KAP3 as bait, we identified HAX-1 in yeast two-hybrid assay of a mouse brain cDNA library. The C-terminal region of HAX-1 interacted with KAP3. Furthermore, using a combination of GST pull-down assay and co-immunoprecipitation, we confirmed that KAP3 interacted with HAX-1 at the protein level. Moreover, we showed that Kinesin-II complex can be co-precipitated with HAX-1. Although we did not identified the HAX-1 containing cargoes, this result suggest that Kinesin-II transports HAX-1 containing cargo through the interaction between KAP3 and HAX-1.

HAX-1 was first identified as a partial cDNA for mRNAs induced upon exposure of macrophages to silica. HAX-1 is ubiquitously expressed and a multifunctional protein [20]. Recent studies have shown that HAX-1 interacts with a number of cellular and viral proteins [5]. HAX-1 interacts with HtrA2 (high temperature requirement protein A2) and Parl (presenilin-associated, rhomboid-like) within mitochondria. This interaction was shown to be required to suppress apoptosis in lymphocytes and neurons [3]. In other study, it was suggested that HAX-1 is involved in the formation of cell-matrix contacts through its binding to the polycystic kidney disease protein PKD2 as well as to cortactin, an F-actin -associated protein [6]. In additional study, HAX-1 was shown to bind the integrin $\beta_{6}$ subunit and regulate the internalization of the integrin $a_{v} \beta_{6}$ [17]. Reduction of HAX-1 expression level by siRNA showed that integrin dependent cell migration was reduced through down regulation of endocytosis via a clathrin [17]. A recent study revealed that HAX-1 interacts with the HIV-1 Rev protein and facilitates the export of viral mRNAs. In HAX-1 and Rev co-expressing cells, Rev was transported from the nucleus to the cytoplasm, where it co-localized with HAX-1 in the cytoplasm [14].

As described in this study, KAP3 directly interacted with HAX-1. These data suggested that KAP3 may link Kinesin-II and HAX-1. We propose one possibility to illustrate how Kinesin-II can mediate the transport of many cargoes. Different cargoes may use different adaptor proteins that mediate the attachment of Kinesin-II to proteins or membrane-bound cargoes. Based on the ability of KAP3 to bind both KIF3A/KIF3B and HAX-1, associated with various cellular and viral proteins, we favor the model that HAX-1 may function as an adaptor and mediate the attachment of many different cargoes to Kinesin-II. In this report, we describe that the C-terminal of HAX-1 mediates interaction with
KAP3. This interaction may link Kinesin-II to many different cargoes.

\section{Acknowledgement}

This research was supported by Basic Science Research Program though the National Research Foundation of Korea (NRF) funded by the Ministry of Education, Science and Technology (2010-0021296).

\section{References}

1. Ausubel, F. M., Brent, R., Kingston, R. E., Moore, D. D., Seidman, J. G., Smith, J. A. and Struhl, K. 1998. Current Protocols in Molecular Biology. John Wiley \& Sons.

2. Brady, S. T. 1985. A novel brain ATPase with properties expected for the fast axonal transport motor. Nature 317, 73-75.

3. Chao, J. R., Parganas, E., Boyd, K., Hong, C. Y., Opferman, J. T. and Ihle, J. N. 2008. HAX1-mediated processing of HtrA2 by Parl allows survival of lymphocytes and neurons. Nature 452, 98-102.

4. Davenport, J. R., Watts, A. J., Roper, V. C., Croyle, M. J., van Groen, T., Wyss, J. M., Nagy, T. R., Kesterson, R. A. and Yoder, B. K. 2007. Disruption of intraflagellar transport in adult mice leads to obesity and slow-onset cystic kidney disease. Curr Biol 17, 1586-1594.

5. Fadeel, B. and Grzybowska, E. 2009. HAX-1: a multifunctional protein with emerging roles in human disease. Biochim Biophys Acta 1790, 1139-1148.

6. Gallagher, A. R., Cedzich, A., Gretz, N., Somlo, S. and Witzgall, R. 2000. The polycystic kidney disease protein PKD2 interacts with HAX-1, a protein associated with the actin cytoskeleton. Proc Natl Acad Sci USA 97, 4017-4022.

7. Hirokawa, N., Niwa, S. and Tanaka, Y. 2010. Molecular motors in neurons: transport mechanisms and roles in brain function, development, and disease. Neuron 68, 610-638.

8. Hirokawa, N., Tanaka, Y. and Okada, Y. 2012. Cilia, KIF3 molecular motor and nodal flow. Curr Opin Cell Biol 24, 31-39.

9. Hirokawa, N. 1998. Kinesin and dynein superfamily proteins and the mechanism of organelle transport. Science 279, 519-526.

10. Kanai, Y., Okada, Y., Tanaka, Y., Harada, A., Terada, S. and Hirokawa, N. 2000. KIF5C, a novel neuronal kinesin enriched in motor neurons. J Neurosci 20, 6374-6384.

11. Kim, S. J., Lee, C. H., Park, H. Y., Yea, S. S., Jang, W. H., Lee, S. K., Park, Y. H., Cha, O. S., Moon, I. S. and Seog, D. H. 2007. JSAP1 interacts with kinesin light chain 1 through conserved binding segments. J Life Sci 17, 889-895.

12. Kozminski, K. G., Beech, P. L. and Rosenbaum, J. L. 1995. The Chlamydomonas kinesin-like protein FLA10 is involved in motility associated with the flagellar membrane. J Cell Biol 131, 1517-1527. 
13. Lin, F., Hiesberger, T., Cordes, K., Sinclair, A. M., Goldstein, L. S., Somlo, S. and Igarashi, P. 2003. Kidney-specific inactivation of the KIF3A subunit of kinesin-II inhibits renal ciliogenesis and produces polycystic kidney disease. Proc Nat1 Acad Sci USA 100, 5286-5291.

14. Modem, S. and Reddy, T. R. 2008. An anti-apoptotic protein, HAX-1, inhibits the HIV-1 rev function by altering its sub-cellular localization. J Cell Physiol 214, 14-19.

15. Mueller, J., Perrone, C. A., Bower, R., Cole, D. G. and Porter, M. E. 2005. The FLA3 KAP subunit is required for localization of kinesin-2 to the site of flagellar assembly and processive anterograde intraflagellar transport. $\mathrm{Mol} \mathrm{Biol} \mathrm{Cell}$ 16, 1341-1354.

16. Ou, G., Koga, M., Blacque, O. E., Murayama, T., Ohshima, Y., Schafer, J. C., Li, C., Yoder, B. K., Leroux, M. R. and Scholey, J. M. 2007. Sensory ciliogenesis in Caenorhabditis elegans: assignment of IFT components into distinct modules based on transport and phenotypic profiles. Mol Biol Cell 18, 1554-1569.

17. Ramsay, A. G., Keppler, M. D., Jazayeri, M., Thomas, G. J., Parsons, M., Violette, S., Weinreb, P., Hart, I. R. and Marshall, J. F. 2007. HS1-associated protein X-1 regulates carcinoma cell migration and invasion via clathrin-mediated endocytosis of integrin alphavbeta6. Cancer Res 67, 52755284.

18. Sarpal, R., Todi, S. V., Sivan-Loukianova, E., Shirolikar, S.,
Subramanian, N., Raff, E. C., Erickson, J. W., Ray, K. and Eberl, D. F. 2003. Drosophila KAP interacts with the kinesin II motor subunit KLP64D to assemble chordotonal sensory cilia, but not sperm tails. Curr Biol 13, 1687-1696.

19. Shimizu, K., Kawabe, H., Minami, S., Honda, T., Takaishi, K., Shirataki, H. and Takai, Y. 1996. SMAP, an Smg GDS-associating protein having arm repeats and phosphorylated by Src tyrosine kinase. J Biol Chem 271, 27013-27017.

20. Suzuki, Y., Demoliere, C., Kitamura, D., Takeshita, H., Deuschle, U. and Watanabe, T. 1997. HAX-1, a novel intracellular protein, localized on mitochondria, directly associates with HS1, a substrate of Src family tyrosine kinases. J Immunol 158, 2736-2744.

21. Tabish, M., Siddiqui, Z. K., Nishikawa, K. and Siddiqui, S. S. 1995. Exclusive expression of C. elegans osm-3 kinesin gene in chemosensory neurons open to the external environment. J Mol Biol 247, 377-389.

22. Takeda, S., Yamazaki, H., Seog, D. H., Kanai, Y., Terada, S. and Hirokawa, N. 2000. Kinesin superfamily protein 3 (KIF3) motor transports fodrin-associating vesicles important for neurite building. J Cell Biol 148, 1255-1265.

23. Yamazaki, H., Nakata, T., Okada, Y. and Hirokawa, N. 1996. Cloning and characterization of KAP3: a novel kinesin superfamily-associated protein of KIF3A/3B. Proc Natl Acad Sci USA 93, 8443-8448.

\title{
초록 : Kinesin superfamily-associated protein 3 (KAP3)를 통한 HS-1-associated protein X-1 (HAX-1)과 Kinesin-II의 결합
}

\author{
장원희 · 석대현* \\ (인제대학교 의과대학 생화학교실)
}

Kinesin-II는 다양한 운반체들을 미세소관을 따라 운반하는 motor 단백질의 하나이다. Kinesin-II는 두 개의 motor 단백질 $\mathrm{KIF} 3 \mathrm{~A}$ 와 $\mathrm{KIF} 3 \mathrm{~B}$, 그리고 motor 단백질의 말단에 결합하는 kinesin superfamily-associated protein 3 (KAP3)로 구성되어 있다. KAP3는 Kinesin-II의 기능에 중요한 역할을 하는 것으로 알려져 있으나 명확한 기능은 아직 밝혀지지 않았다. 본 연구에서 KAP3와 결합하는 단백질을 분리하기 위하여 효모 two-hybrid system을 사용하여 탐색한 결과 HS-1-associated protein X-1 (HAX-1)을 분리하였다. KAP3은 HAX-1의 C-말단 부위와 결합하며, HAX-1은 KAP3의 C말단부위와 결합함을 효모 two-hybrid assay로 확인하였다. 그러나, HAX-1는 KIF3A, KIF3B, KIF5B, 그리고 kinesin light chain (KLC)과는 결합하지 않았다. KAP3와 HAX-1의 단백질 결합은 glutathione $S$-transferase (GST) pull-down assay와 공동면역침강으로 추가 확인하였다. 생쥐의 뇌 파쇄액을 HAX-1 항체와 KIF3A 항체로 면역침강을 행한 결과 Kinesin-II의 구성단백질인 KIF3B와 KAP3가 같이 침강하였다. 이러한 결과들은 KAP3가 Kinesin-II와 HAX-1의 결합을 매개한다는 것을 시사한다. 